\title{
Phytoremediation Potential of Castor Bean (Ricinus Communis L.)
}

\author{
Violina Angelova ${ }^{1 *}$ and Mariana Perifanova Nemska ${ }^{2}$ \\ ${ }^{1}$ Department of Chemistry, Agricultural University-Plovdiv, Bulgaria \\ ${ }^{2}$ University of Food Technologies-Plovdiv, Plovdiv, Bulgaria \\ *Corresponding Author: Violina Angelova, Department of Chemistry, Agricul- \\ tural University-Plovdiv, Bulgaria .
}

DOI: 10.31080/ASAG.2020.04.0893
Received: July 29, 2020

Published: August 28, 2020

(C) All rights are reserved by Violina

Angelova and Mariana Perifanova

Nemska.

\begin{abstract}
The goal of this research was to investigate the potential use of Ricinus communis L. (castor oil plant) for the remediation of metalpolluted sites. This field study was performed in industrially polluted soils that contain high concentrations of $\mathrm{Zn}, \mathrm{Pb}$ and $\mathrm{Cd}$ situated at different distances $(0.1,2.0$ and $15.0 \mathrm{~km})$ from the source of pollution - KCM (Non-Ferrous Metal Works) near Plovdiv, Bulgaria. The amount of heavy metals in different part of castor oil plant (roots, stems, leaves, capsule, seeds) and oils was determined by ICP. The castor oil plant is tolerant to heavy metals. Bioaccumulation factor and translocation factor values were greater than one, which suggests that heavy metals accumulate efficiently in the shoots. The presence of low levels of saturated and polyunsaturated fatty acids as well as high levels of monounsaturated acids result in the production of a high quality biodiesel. The castor bean is a plant that can be used simultaneously for phytoextraction of heavy metals from soils and as biofuel. It can be grown on soils heavily contaminated with heavy metals, which are not suitable for the cultivation of food crops.
\end{abstract}

Keywords: Castor Oil Plant; Heavy Metals; Oil; Phytoremediation; Polluted Soils

\section{Abbreviations}

KCM: Non-Ferrous Metal Works; DDT: Dichlorodiphenyltrichloroethane; TF: Translocation Factor; BF: Bioaccumulation Factor.

\section{Introduction}

Phytoremediation is an emerging technology, which should be considered for remediation of contaminated sites because of its cost effectiveness, aesthetic advantages and long-term applicability [1,2]. This technology can be defined as the efficient use of plants to remove, detoxify or immobilize environmental contaminants in soils, waters or sediments through the natural, biological, chemical or physical activities and processes of the plants [3-5]. This technique has many advantages compared to other remediation procedures, namely low economic costs and the possibility of being applied to soils with a minimal environmental impact.
The use of crop plants for phytoremediation of contaminated soils has the advantage of high biomass production and the capacity to adapt to variable environments [6]. However, in order to succeed they must have a tolerance to the contaminants and be capable of accumulating significant concentrations of heavy metals within their tissue. Additionally, crops could make the long periods of time required for decontamination more acceptable, both economically and environmentally. If the contaminated biomass can also be further processed for added value products (in addition to being concentrated on deposits of hazardous wastes), then this would represent an improvement to the economic efficiency of phytoremediation technology. Industrial plants, i.e. energy crops or crops for bio-diesel production, are therefore prime candidates for phytoremediation [7]. 
The castor oil plant belongs to the family Eurphorbiacae and is considered a metal-tolerant plant that has the ability to grow in highly contaminated soils and has the potential for phytoremediation [8-12]. The plant is found in nature as an uncultivated and cultivated plant in most tropical and subtropical countries. It can be grown at low cost and can tolerate different weather conditions. In recent years, this plant has generated a growing interest due to the use of the oil for non-food purposes, as a biofuel and in the production of biodiesel fuel, and due to the high oil content in its seeds [11]. About $1 \mathrm{Mt}$ of the castor oil plant is currently used annually in the production of oil, of which India, China and Brazil are the main producers [13,14]. Kulkarni and Sawant [15] reported that the castor oil plant is a crop with high yield and contains 35$55 \%$ oil, and the oil produced has the highest viscosity of vegetable oils, with a molecular weight of 298. Castor oil contains ricinoleic acid [16]. The hydroxyl group is present at C12 in ricinoleic acid and causes the ricinoleic acid to have an unusual level of polarity, and permits chemical derivatization which is not possible for most other vegetable oils. The oil can be used in the manufacture of stain removal (Vanish), lubricants, protective coatings, varnish, cosmetics, paints and inks, and is the main raw material used in the production of nylon and other synthetic fibers and resins, as well as the main ingredient in the oil for car and motorcycle engines [17]. These qualities all make the castor oil plant an extremely strong candidate for its simultaneous use in phytoremediation of contaminated soils and bioenergy production [11]. In literature studies have been conducted on the absorption of heavy metals by the castor oil plant in its cultivation in pot experiments and on tailing ponds of mining activity; however very often the results obtained are contradictory. According to Kiran., et al. [14] and Khan., et al. [18] castor oil plant is suitable for phytoextraction, Olivares., et al [11] and Zhang., et al. [19] suggest that this plant is suitable for phytostabilization, while Costa., et al. [20] finds that castor bean can be used as an indicator plant for cadmium. In literature there is no information on the absorption of heavy metals by the castor oil plant, and the potential for phytoremediation through the cultivation of the castor oil plant in temperate regions as well as on contaminated soil from metallurgical activities, where it is grown as an annual plant. The purpose of this study is to comparatively determine the quantities and depots for the accumulation of $\mathrm{Pb}, \mathrm{Cd}$ and $\mathrm{Zn}$ in the vegetative and reproductive organs of the castor oil plant and oils, and to assess its potential for phytoremediation of heavy metal polluted soils.

\section{Materials and Methods}

The field tests were set after the block method in four replications. The size of the test parcel was $25 \mathrm{~m}^{2}$. Castor oil plant was sown in early April at a distance of $70 \times 70 \mathrm{~cm}$ with 2 plants nested at a depth of 8-10 cm. Castor oil plant was grown using the conventional technology on areas located at different distances $(0.1$ $\mathrm{km}, 2 \mathrm{~km}$ and $15 \mathrm{~km}$ ) from the source of contamination - KCM Plovdiv (Non-Ferrous Metal Works). Four plants from each replication were used in the analysis.

The castor oil plants were gathered for analysis upon reaching commercial ripeness. Samples from the root, stem and leaf were dried at room temperature to obtain an air-dry mass and then dried at $105^{\circ} \mathrm{C}$. In laboratory conditions, oil was obtained from its seeds by extraction using a Soxhlet apparatus.

The pseudo-total composition of metals in soils was determined in accordance with ISO 11466 [21]. The available (mobile) heavy metals contents were extracted by a solution of DTPA [22]. The composition of heavy metals $(\mathrm{Pb}, \mathrm{Zn}$ and $\mathrm{Cd}$ ) within the plant components (roots, stems, leaves, capsules, and seeds) and within the oils of the castor bean was determined through the method of the microwave mineralization. The ICP method was used to carry out quantitative measurements (Jobin Yvon Emission - JY 38 S, France). Analytical efficiency and digestion of ICP was validated using apple leaves as a standard reference material (SRM 1515, National Institute of Standards and Technology, NIST).

The extraction method was used to determine the content of oil in castor bean by weight. Methyl esters of the fatty acids in the oils were prepared in order to determine the composition of the fatty acids in the oils, in accordance with the procedures described in ISO 5509 [23]. The analysis of the methyl esters of the fatty acids was carried out by gas chromatography, in accordance with ISO 5508 [24].

Statistical analyses were conducted using Statistica version 7.0.

\section{Results and Discussion}

Soils

The results presented in table 1 show that the soil contamination in the area of KCM - Plovdiv is on the torch of contamination, 
with a notable decrease observed in the total content of heavy metals in the soil as the distance from KCM - Plovdiv increased. Soil samples obtained from areas located at distances of $0.1 \mathrm{~km}$ and $2.0 \mathrm{~km}$ from KCM had reported values for $\mathrm{Pb}$ of $913.5 \mathrm{mg} \cdot \mathrm{kg}^{-1}$ and $2576 \mathrm{mg} \cdot \mathrm{kg}^{-1}$ respectively, which both exceed the maximum permissible concentration (MPC). The content of $\mathrm{Pb}$ was found to be significantly reduced to $24.6 \mathrm{mg} . \mathrm{kg}^{-1}$ in the area located $15 \mathrm{~km}$ from KCM. Similar results were obtained for $\mathrm{Zn}$ and $\mathrm{Cd}$. In the area located $0.1 \mathrm{~km}$ from KCM the content of $\mathrm{Zn}$ and $\mathrm{Cd}$ were reported to be $1903.8 \mathrm{mg} . \mathrm{kg}^{-1}$ and $26.2 \mathrm{mg} . \mathrm{kg}^{-1}$ respectively which both significantly exceed the MPC, while values of $1564.0 \mathrm{mg} . \mathrm{kg}-1 \mathrm{Zn}$ and $40.5 \mathrm{mg} . \mathrm{kg}^{-1} \mathrm{Cd}$ were reported at a distance of $2.0 \mathrm{~km}$ from KCM. In a remote area (15 km from KCM) 33.9 mg.kg ${ }^{-1} \mathrm{Zn}$ and $2.7 \mathrm{mg} . \mathrm{kg}^{-1}$ Cd were found.

\begin{tabular}{|l|c|c|c|}
\hline Parameter & $\begin{array}{c}\text { Soil1 (S1) } \\
\mathbf{0 . 1} \mathbf{~ k m}\end{array}$ & $\begin{array}{c}\text { Soil 2 (S2) } \\
\mathbf{2} \mathbf{~ k m}\end{array}$ & $\begin{array}{c}\text { Soil 3 (S3) } \\
\mathbf{1 5} \mathbf{~ k m}\end{array}$ \\
\hline pH & $7.4 \pm 0.1$ & $6.4 \pm 0.1$ & $7.5 \pm 0.1$ \\
\hline EC, dS.m ${ }^{-1}$ & $0.15 \pm 0.01$ & $0.15 \pm 0.1$ & $0.15 \pm 0.01$ \\
\hline Organic C,\% & $2.20 \pm 0.05$ & $2.24 \pm 0.05$ & $1.54 \pm 0.05$ \\
\hline N Kjeldal,\% & $0.22 \pm 0.02$ & $0.38 \pm 0.02$ & $0.13 \pm 0.02$ \\
\hline P, mg.kg-1 & $625.6 \pm 2.5$ & $707.4 \pm 2.8$ & $354.9 \pm 1,8$ \\
\hline K, mg.kg-1 & $6960.0 \pm 3.5$ & $7700.4 \pm 3.7$ & $6780.0 \pm 3.5$ \\
\hline Pb, mg.kg-1 & $913.5 \pm 6.0$ & $2576.0 \pm 9.2$ & $24.6 \pm 0.5$ \\
\hline Cd, mg.kg ${ }^{-1}$ & $11.5 \pm 0.5$ & $40.5 \pm 1.8$ & $2.7 \pm 0.1$ \\
\hline Zn, mg.kg ${ }^{-1}$ & $1903.5 \pm 8.7$ & $1564.0 \pm 7.5$ & $33.9 \pm 0.7$ \\
\hline
\end{tabular}

Table 1: Characterization of the soils.

x: Average value (mg.kg-1) from 5 repetitions; sd: Mean standard deviation.

MPC (pH 6.0-7.4) - Pb-60 mg.kg-1, Cd-2.0 mg.kg-1 ${ }^{-1}$ n-320 mg.kg-1. MPC (pH > 7.4) - Pb-100 mg.kg-1 , Cd-3.0 mg.kg-1, Zn-400 mg.kg-1.

Table 2 also shows the percentage of mobile forms relative to the total amount of the elements comprised in the soil. The results obtained for the mobile forms of the metals designated by DTPA indicate that mobile forms of $\mathrm{Cd}$ in the contaminated soils make up the most substantial portion of its total concentration, and range from $35.1 \%$ to $70.6 \%$, which is followed by $\mathrm{Pb}$ with $21.3 \%$ to $42.0 \%$ and $\mathrm{Zn}$ with $13.5 \%$ to $33.7 \%$. It is notable that there is significantly higher content of mobile forms of heavy metals in the soil situated at a distance of $2 \mathrm{~km}$ from $\mathrm{KCM}$, and they are characterized by a low acid reaction. Mobile forms of $\mathrm{Cd}$ comprise the most substantial portion of uncontaminated soil and reach up to 24.8\%, followed by $\mathrm{Pb}$ with $8.5 \%$ and $\mathrm{Zn}$ with $7.1 \%$.

\begin{tabular}{|l|c|c|c|c|c|c|}
\hline $\begin{array}{c}\text { Distance, } \\
\text { km }\end{array}$ & \multicolumn{2}{|c|}{ Pb } & \multicolumn{2}{c|}{ Cd } & \multicolumn{2}{c|}{ Zn } \\
\hline & $\mathrm{mg.kg}^{-1}$ & $\%^{*}$ & $\mathrm{mg.kg}^{-1}$ & $\%^{*}$ & $\mathrm{mg.kg}^{-1}$ & $\%^{*}$ \\
\hline S1 & $\begin{array}{c}194.7 \pm \\
2.4\end{array}$ & 21.3 & $\begin{array}{c}9.2 \pm \\
0.5\end{array}$ & 35.1 & $\begin{array}{c}257.0 \pm \\
1.0\end{array}$ & 13.5 \\
$(0.1 \mathrm{~km})$ & 2.4 & & 0.5 & & \\
\hline S2 & $104.0 \pm$ & 42.1 & $\begin{array}{c}28.6 \pm \\
1.1\end{array}$ & 70.6 & $\begin{array}{c}527.0 \pm \\
1.3\end{array}$ & 33.7 \\
$(2.0 \mathrm{~km})$ & 6.5 & & $0.67 \pm$ & 24.8 & $\begin{array}{c}2.4 \pm \\
0.1\end{array}$ & 7.1 \\
\hline S3 (15 km) & $2.1 \pm 0.1$ & 8.5 & 0.05 & & 0.1 & \\
\hline
\end{tabular}

Table 2: DTPA - extractable Pb, Cd and Zn (mg.kg-1) in soils sampled from KCM.

*DTPA -extractable/total content

$\mathrm{x}$ : Average value (mg.kg-1) from 5 repetitions; sd: Mean standard deviation.

Castor oil plant

The cultivation of the castor oil plant on contaminated and uncontaminated soils presented significant differences in the distribution of metals throughout the different parts of the plant. Large portions of $\mathrm{Pb}, \mathrm{Cd}, \mathrm{Zn}$ are accumulated in the root system, the amount and extent of which primarily depend on the content of heavy metals in the soil. The content of $\mathrm{Pb}$ present in the root system of the castor oil plant, grown at distances of 0.1 and $2 \mathrm{~km}$ from $\mathrm{KCM}$, ranges from 236.0 to $506.0 \mathrm{mg} \cdot \mathrm{kg}^{-1}, \mathrm{Zn}$ - from 256.9 to 410.9 mg.kg-1 and Cd - 5.9 to 17.1 mg.kg-1 (Table 3). Significantly lower values are reported for the castor oil plant grown in the region $15 \mathrm{~km}$ away from KCM, - $6.2 \mathrm{mg} \cdot \mathrm{kg}^{-1} \mathrm{~Pb}, 57.5 \mathrm{mg} \cdot \mathrm{kg}^{-1} \mathrm{Zn}$ and 0.12 mg.kg-1 Cd. The content of heavy metals in the roots is higher in the cultivation of the castor oil plant on soil at a distance of $2 \mathrm{~km}$ from the KCM (with the highest content of heavy metals (total and mobile forms) and low acid reaction), while in the cultivation on soil at a distance of $0.1 \mathrm{~km}$ from KCM (high content of heavy metals and alkaline reaction) the content of heavy metals was found to be lower. The main factors contributing to this are the locations at which the experiments were conducted, the torch of pollution and the content of heavy metals in the soil. The site located at a distance of $2 \mathrm{~km}$ lies on the torch of pollution, while the site located at a distance of 0.1 $\mathrm{km}$ partially lies on the torch of pollution. A relationship has been established between the mobile forms of heavy metals in the soil and the content of heavy metals in the roots of the castor oil plant. 


\begin{tabular}{|l|c|c|c|c|}
\hline & & $\mathbf{S 1}$ & $\mathbf{S 2}$ & $\mathbf{S 3}$ \\
& & $\mathbf{x} \pm \mathbf{~ s d}$ & $\mathbf{x} \pm \mathbf{s d}$ & $\mathbf{x} \pm \mathbf{~ d}$ \\
\hline $\mathrm{Pb}$ & Roots & $236.0 \pm 2.1$ & $506.0 \pm 2.6$ & $6.2 \pm 0.3$ \\
\hline & Stems & $35.1 \pm 0.2$ & $349.3 \pm 2.4$ & $2.7 \pm 0.1$ \\
\hline & Leaves & $410.1 \pm 2.4$ & $4347.1 \pm 12.5$ & $10.9 \pm 0.4$ \\
\hline & Capsule & $63.5 \pm 0.6$ & $1985.4 \pm 8.6$ & $4.1 \pm 0.2$ \\
\hline & Seeds & $1.5 \pm 0.1$ & $372.7 \pm 2.3$ & $2.3 \pm 0.1$ \\
\hline & Oil & $0.7 \pm 0.05$ & $3.9 \pm 0.1$ & $0.05 \pm 0.01$ \\
\hline $\mathrm{Zn}$ & Roots & $256.9 \pm 1.2$ & $410.9 \pm 1.7$ & $57.5 \pm 0.6$ \\
\hline & Stems & $145.3 \pm 1.0$ & $314.0 \pm 1.3$ & $18.0 \pm 0.2$ \\
\hline & Leaves & $314.2 \pm 1.6$ & $2484.3 \pm 69.7$ & $55.6 \pm 0.6$ \\
\hline & Capsule & $44.3 \pm 0.5$ & $970.8 \pm 3.6$ & $9.2 \pm 0.2$ \\
\hline & Seeds & $98.8 \pm 0.9$ & $95.7 \pm 0.9$ & $80.0 \pm 0.9$ \\
\hline & Oil & $3.4 \pm 0.1$ & $4.6 \pm 0.2$ & $1.2 \pm 0.1$ \\
\hline $\mathrm{Cd}$ & Roots & $5.9 \pm 0.2$ & $17.1 \pm 0.5$ & $0.12 \pm 0.01$ \\
\hline & Stems & $1.9 \pm 0.05$ & $8.1 \pm 0.2$ & $0.11 \pm 0.01$ \\
\hline & Leaves & $8.1 \pm 0.05$ & $156.9 \pm 1.2$ & $0.12 \pm 0.01$ \\
\hline & Capsule & $1.8 \pm 0.03$ & $44.0 \pm 0.3$ & $0.15 \pm 0.01$ \\
\hline & Seeds & $0.3 \pm 0.02$ & $1.5 \pm 0.03$ & $0.07 \pm 0.01$ \\
\hline & Oil & $0.12 \pm 0.01$ & $0.24 \pm 0.01$ & $0.12 \pm 0.01$ \\
\hline & & & & \\
\hline
\end{tabular}

Table 3: Content of $\mathrm{Pb}, \mathrm{Zn}$ and $\mathrm{Cd}\left(\mathrm{mg}_{\mathrm{kg}}{ }^{-1}\right)$ in castor oil plant. $\mathrm{X}$ : Average value (mg.kg-1) from 5 repetitions; sd: Mean standard deviation.

In order to establish the detailed distribution of heavy metals in the root system of the castor oil plant, we did further research on the content of heavy metals in the main root and the feeding roots of the castor oil plant grown at a distance of $2 \mathrm{~km}$ from KCM. The content of $\mathrm{Pb}$ in the main root of the castor oil plant reaches up to $99 \mathrm{mg} . \mathrm{kg}^{-1}, \mathrm{Zn}$ - up to $87.1 \mathrm{mg} \cdot \mathrm{kg}^{-1}$ and $\mathrm{Cd}-\mathrm{up}$ to $2.3 \mathrm{mg} \cdot \mathrm{kg}^{-1}$, while $\mathrm{Pb}$ in the feeding roots reaches up to $329.4 \mathrm{mg} \cdot \mathrm{kg}^{-1}, \mathrm{Zn}-\mathrm{up}$ to $337.8 \mathrm{mg} . \mathrm{kg}^{-1}$ and $\mathrm{Cd}$ - to $11.2 \mathrm{mg.kg}{ }^{-1}$ (Figure 1). A larger part of the heavy metals contained in the soil are fixed and accumulated in the feeding roots of the castor oil plant, in comparison to lower proportion observed in the tap root. The reason for this is that the root system of the castor oil plant is characteristic of annual plants, which consists of a thick tap root that reaches up to $2 \mathrm{~m}$ depth, and 3-6 well-developed lateral roots that have an extremely dense network of root hairs [12].

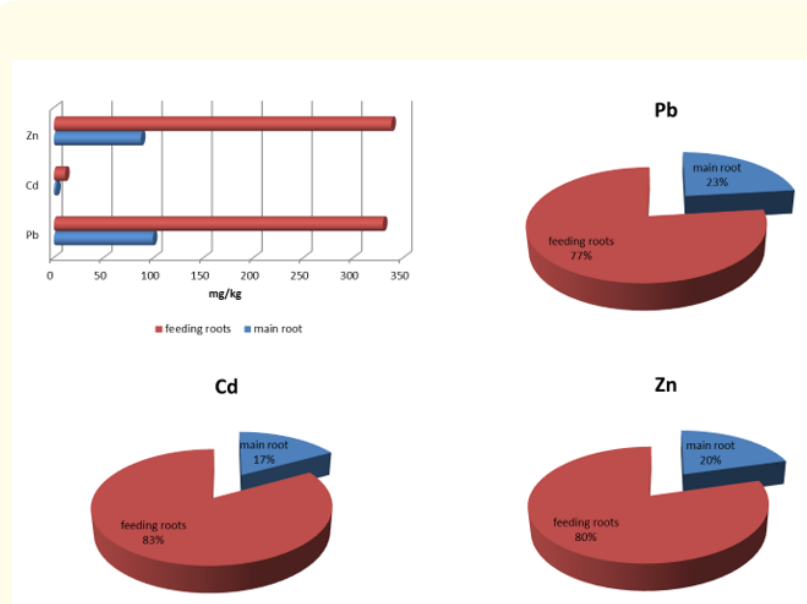

Figure 1: Content of $\mathrm{Pb}, \mathrm{Zn}$ and $\mathrm{Cd}\left(\mathrm{mg}_{\mathrm{kg}}{ }^{-1}\right)$ in main root and feeding roots in castor oil plant.

The content of heavy metals in the feeding roots is much higher because they are located mainly in the plow layer. Perhaps this is the reason large amounts of heavy metals accumulate in the root system when cultivated on heavy metal polluted soils.

The results obtained indicate that a notable portion of the heavy metals accumulate in the roots, consistent with the results found by other authors $[12,25,26]$. The explanation for this is that the penetration of heavy metals in the plasma results in the formation of low mobile compounds with organic substance, and this causes inactivation and disposal of significant quantities of the heavy metals.

Cultivation of the castor oil plant on highly contaminated soils results in the content of heavy metals in the stems being at levels comparable to that of the feeding roots, while its cultivation on uncontaminated soils results in significantly lower content of heavy metals in the stems compared with the root system. This indicates that their movement within the vascular system is severely limited. In the stems of the castor oil plant grown at 0.1 and $2 \mathrm{~km}$ from KCM the content of $\mathrm{Pb}$ ranges from 35.1 to $349.3 \mathrm{mg} \cdot \mathrm{kg}^{-1}$, $\mathrm{Zn}$ from 145.3 to $314.0 \mathrm{mg} \cdot \mathrm{kg}^{-1}$, and $\mathrm{Cd}$ from 1.9 to $8.1 \mathrm{mg} \cdot \mathrm{kg}^{-1}$, while in the remote area the content of $\mathrm{Pb}$ reaches up to $2.7 \mathrm{mg} \cdot \mathrm{kg}^{-1}, \mathrm{Zn}-18.0 \mathrm{mg} \cdot \mathrm{kg}^{-1}$ and Cd - up to 0.11 mg. $\mathrm{kg}^{-1}$.

The content of heavy metals in the leaves of the castor oil plant is higher than that of the root system and the stems in the cultiva- 
tion of the castor oil plant on heavy metals polluted soils. In the leaves of the castor oil plant grown at 0.1 and $2 \mathrm{~km}$ from KCM, the content of $\mathrm{Pb}$ ranges from 410.1 to $4347.1 \mathrm{mg} \cdot \mathrm{kg}^{-1}, \mathrm{Zn}$ - from 314.2 to $2484.3 \mathrm{mg} . \mathrm{kg}^{-1}$ and $\mathrm{Cd} 8.1$ to $156.9 \mathrm{mg} \cdot \mathrm{kg}^{-1}$, while in the remote area the content of $\mathrm{Pb}$ reaches up to $10.9 \mathrm{mg} \cdot \mathrm{kg}^{-1}, \mathrm{Zn}$ - up to 55.6 mg.kg-1 and Cd - up to 0.12 mg. $\mathrm{kg}^{-1}$.

The obtained results demonstrate the unique ability of the castor oil plant to accumulate $\mathrm{Pb}$ in its leaves when cultivated on heavy metal polluted soils. This may perhaps be attributable to the anatomical and morphological characteristics of the crop. The leaves of the castor oil plant are large, palmately cut and covered with a waxy coating.

The ratio of heavy metals in the above-ground mass to those in the roots of the castor oil plant grown on the soils polluted with heavy metals under field conditions is higher than 1 , and hence the castor oil plant is an accumulator of heavy metals and can therefore be used for the purpose of phytoextraction of heavy metals from the soil. The obtained results are inconsistent with Huang., et al. [10], who established that Cd is mainly accumulated in the roots of the castor oil plant when cultivated in pot experiments on soils contaminated with both Cd and DDT (Dichlorodiphenyltrichloroethane). The obtained results also do not confirm results of Olivares., et al. [11] and Varun., et al. [27], according to whom the content of $\mathrm{Pb}$ in the roots is much higher than that of the aboveground mass in its cultivation on tailings ponds from mining activities, and on industrial or residential areas containing heavy metals.

The observed differences in the behavior of the castor oil plant and its ability to absorb heavy metals when cultivated on tailings and contaminated soils from metallurgical activity is probably due to the fact that in the terms of our experiment (in the temperate zone) the castor oil plant is grown as an annual plant, unlike in tropical Africa and areas with dry climates where the castor oil plant is grown as a perennial plant.

The content of heavy metals in the fruit (capsule) of the castor oil plant was also determined. In the fruit of the castor oil plant grown at a distance of 0.1 and $2 \mathrm{~km}$ from KCM, the content of $\mathrm{Pb}$ ranges from 63.5 to $1985.4 \mathrm{mg} \cdot \mathrm{kg}^{-1}, \mathrm{Zn}$ - from 44.3 to $970.8 \mathrm{mg} \cdot \mathrm{kg}^{-1}$ and $\mathrm{Cd}$ from 1.8 to $44.0 \mathrm{mg} \cdot \mathrm{kg}^{-1}$, while in the remote area the $\mathrm{Pb}$ content reaches up to $0.15 \mathrm{mg} . \mathrm{kg}^{-1}, \mathrm{Zn}-$ up to $9.2 \mathrm{mg} \cdot \mathrm{kg}^{-1}$ and $\mathrm{Cd}$ up to 0.15 mg.kg-1.
There is significantly lower heavy metal content in the seeds compared to the root system of the plant and its above-ground mass (stems and leaves) and its fruits (capsule). The results obtained clearly show that the capsule acts as a filter along the path that the heavy metals take towards the seeds. Perhaps in the vascular system the heavy metals are moved from the soil toward the seeds and are accumulated there. In the seeds of the castor oil plant grown at a distance of 0.1 to $2 \mathrm{~km}$ from $\mathrm{KCM}$, the content of $\mathrm{Pb}$ ranges from

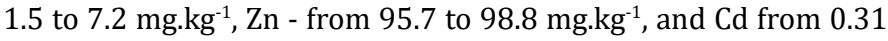
to $1.48 \mathrm{mg} \cdot \mathrm{kg}^{-1}$, while in the remote area the content of $\mathrm{Pb}$ reaches up to $0.28 \mathrm{mg} . \mathrm{kg}^{-1}, \mathrm{Zn}-50.0 \mathrm{mg} . \mathrm{kg}^{-1}$ and $\mathrm{Cd}-\mathrm{up}$ to $0.07 \mathrm{mg} . \mathrm{kg}^{-1}$.

The results show that during the processing of the seeds, the majority of the heavy metals contained within them do not enter into the oil, and hence their content in the oil is significantly lower. The obtained results confirm what was found by Olivares., et al. [11] and Gonzalez-Chavez., et al. [13]. The content of Pb in the oil of the castor oil plant grown on the contaminated soils ranges from 0.7 to $3.9 \mathrm{mg} . \mathrm{kg}^{-1}, \mathrm{Zn}$ - from 3.4 to $4.6 \mathrm{mg} \cdot \mathrm{kg}^{-1}$ and $\mathrm{Cd}$ from 0.16 to $0.24 \mathrm{mg} \cdot \mathrm{kg}^{-1}$, while in the remote area the content of $\mathrm{Pb}$ reaches up to $0.05 \mathrm{mg} . \mathrm{kg}^{-1}, \mathrm{Zn}$ - up to $1.24 \mathrm{mg} \cdot \mathrm{kg}^{-1}$ and $\mathrm{Cd}-$ up to $0.02 \mathrm{mg} \cdot \mathrm{kg}^{-1}$.

According to Olivares., et al. [11] and Gonzalez-Chavez., et al. [13] no significant differences are observed between the content of metals in the oils of plants from the contaminated areas and uncontaminated areas; however, this is not confirmed by our results.

Heavy metal distribution within the organs of the castor oil plant occurs in a specific manner for each of the individual elements. In the cultivation of the castor oil plant on heavy metal polluted soils the majority of $\mathrm{Pb}$ is accumulated in the leaves (58\%) and a relatively small amount is present in the seeds (5\%). The results are similar for $\mathrm{Cd}$ and $\mathrm{Zn}$ for which the largest portions are accumulated in the leaves (70 and 58\%). The seeds contain merely $1 \%$ of the total amount of $\mathrm{Cd}$ absorbed by the castor oil plant and $2 \%$ of the total amount of absorbed Zn (Figure 2).

\section{Transfer and bioaccumulation factors}

The translocation factor ( $\mathrm{TF}=\mathrm{Cshoots} /$ Croots) and bioaccumulation factor $(\mathrm{BF}=\mathrm{C}$ shoots $/$ Csoils) were calculated in order to categorically determine the ability of the castor oil plant in extracting heavy metals from soil, and to examine the potential of the castor oil plant for phytoextraction. 


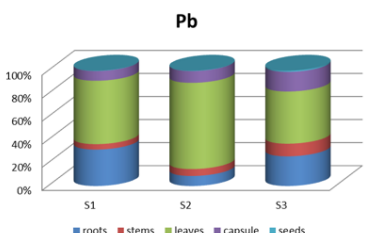

Cd

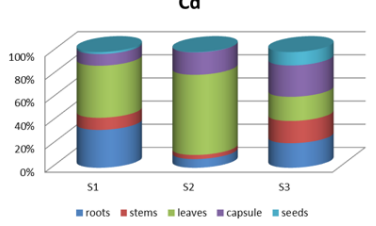

Figure 2: Distribution of $\mathrm{Pb}, \mathrm{Zn}$ and $\mathrm{Cd}$ in vegetative and reproductive organs of castor oil plant.

The obtained results reveal a translocation factor greater than 1 for all metals, regardless of the extent of the contamination of the soil (Table 4). This is the complete converse of the results of Olivares., et al. [11], who found that the castor oil plant has a low translocation factor $(\mathrm{TF})$ of metals $(\mathrm{TF}<1)$ which indicates that there is no translocation of metals from the roots to the various organs of the castor oil plant, and that the castor oil plant is not an accumulator of heavy metals.

\begin{tabular}{|l|c|c|c|c|c|c|}
\hline & \multicolumn{2}{|c|}{ Pb } & \multicolumn{2}{c|}{ Cd } & \multicolumn{2}{c|}{ Zn } \\
\hline & TF & BF & TF & BF & TF & BF \\
\hline S1 & 2.89 & 2.29 & 1.69 & 1.09 & 1.78 & 1.55 \\
\hline S2 & 9.28 & 4.33 & 9.69 & 5.78 & 6.8 & 5.31 \\
\hline S3 & 2.18 & 6.47 & 1.89 & 0.34 & 1.28 & 24.45 \\
\hline
\end{tabular}

Table 4: Translocation (TF) and bioaccumulation (BF) factors in castor oil plant.

$\mathrm{TF}=[\text { Metal }]_{\text {shootst }} /[\text { Metal }]_{\text {roots }} ; \mathrm{BF}=[\text { Metal }]_{\text {shoots }} /[\text { Available metal }]_{\text {soils }}$.

According to most of the published results, this plant behaves like a metal stabilizer and can be used in phytostabilization and immobilization of the metals within the roots of plants [28]. Shi and Cai [26] also found that the TF of the castor oil plant is low, which suggests that this crop has a low capacity to translocate $\mathrm{Cd}$ from the roots to the above-ground mass.
The effectiveness of the phytoextraction is also determined by the bioaccumulation factor. The bioaccumulation coefficient is a measure of the ability of the plant in absorbing and translocating the metals to the above-ground mass such that they can be easily harvested. The obtained results indicate that in terms of $\mathrm{Pb}$ the bioaccumulation factor in the castor oil plant grown on contaminated soils reaches 17.3 , in $\mathrm{Zn}$ up to 21.3 , and in cadmium up to 23.1 (Table 4).

In the previous papers was established that the values for the BF for the above-ground organs of the castor oil plant are lower than 1 $[10,19,26,27]$, and hence can be used in phytostabilization of $\mathrm{Cd}$ in highly Cd-contaminated soils.

The obtained results do not confirm what was found by Olivares., et al. [11], in that the castor oil plant does not have the ability to translocate heavy metals from its roots to its above-ground parts. A probable reason for this is that most studies have been conducted on artificially contaminated soils with further importation of lead and cadmium. The discrepancy between the results is potentially due to the fact that the castor oil plants studied by us are annuals, while those studied by Olivares., et al. [11] are perennial shrubs.

For the cultivation of the castor oil plant on heavy metal polluted soils, both the EF and TF coefficients are greater than 1. Given the values of both coefficients (TF for the capacity of the castor oil plant to translocate the contaminants from the soil, and the value of BAC in its cultivation on soils polluted by heavy metals), it can be claimed that increasing the level of contamination can also result in a corresponding increase in the potential of the castor oil plant to translocate and accumulate $\mathrm{Cd}, \mathrm{Pb}$ and $\mathrm{Zn}$ in its above-ground parts. The castor oil plant may be referred to the group of hyperaccumulators of $\mathrm{Pb}$ and $\mathrm{Cd}$, and the accumulators of $\mathrm{Zn}$, as the contents of $\mathrm{Pb}$ and $\mathrm{Cd}$ in the above-ground mass exceed 1000 and $100 \mathrm{mg} \cdot \mathrm{kg}^{-1}$, respectively. The plants are characterized by their capacity in absorbing and accumulating $\mathrm{Pb}, \mathrm{Cd}$ and $\mathrm{Zn}$, while showing no signs of toxicity (chlorosis and necrosis) in their content of $40.5 \mathrm{mg} \cdot \mathrm{kg}^{-1} \mathrm{Cd}$ and $2576.0 \mathrm{mg} \cdot \mathrm{kg}^{-1} \mathrm{~Pb}$ in the soil, respectively. Taken together, these features make the castor oil plant a potential for phytoextraction of heavy metals. The ideal plant for phytoremediation must have fast growth, deep roots, high biomass production, ease of harvest, tolerance to various metals, and the ability to accumulate these metals in the above-ground parts $[11,25,29,30]$. The obtained results 
strongly indicate that the castor oil plant is a crop that shows a tolerance to heavy metals and is suitable for cultivation in contaminated soils. It can be referred to the group of hyperaccumulators of $\mathrm{Pb}$ and $\mathrm{Cd}$, and the accumulators of $\mathrm{Zn}$ and can successfully be used for phytoremediation of heavy metal polluted soils.

\section{Castor oil}

Mazzani and Rodriguez [31] and Manzano., et al. [32] reported that oil content ranging between 17 and $55 \%$ in castor bean seeds from various different countries. The obtained results in this study show that the content of the oil ranges from $29.2 \%$ to $35.8 \%$ and the fat content of the seeds decreases as the degree of contamination of the soil increases (Table 5).

The composition of fatty acid of the studied oil, extracted from the seeds of the castor oil plant grown at $2 \mathrm{~km}$ from KCM, comprises predominantly of unsaturated fatty acids with a quantity of up to $93.81 \%$. The oil composition is dominated by ricinoleic acid (C18:1r, 77.85\%), followed by oleic acid (C18:1, 13.4\%), linolenic acid (C18:3, 2.01\%) and linoleic acid (C18:2, 0.45\%). The saturated fatty acids predominantly comprise of palmitic acid (C16:0) at $3.95 \%$, followed by stearic acid (2.24\%) (Table 5).

\begin{tabular}{|l|c|c|c|}
\hline \multicolumn{1}{|c|}{ Parameter } & S1 (0.1 km) & S2 (2 km) & $\begin{array}{c}\text { S3 } \\
\mathbf{( 1 5} \\
\mathbf{k m})\end{array}$ \\
\hline Oil content, \% & 32.2 & 29.2 & 35.8 \\
\hline Saturated (S) & 6.19 & 6.39 & 8.45 \\
\hline Palmitic acid C 16:0 & 3.95 & 4.05 & 4.37 \\
\hline Stearic acid C 18:0 & 2.24 & 2.34 & 4.08 \\
\hline Unsaturated (MUFA) & 91.35 & 91.1 & 89.15 \\
\hline Oleic acid C 18:1 & 13.4 & 14.5 & 16.09 \\
\hline Ricinoleic acid C 18:1 r & 77.95 & 76.6 & 73.06 \\
\hline Unsaturated (PUFA) & 2.46 & 2.51 & 2.4 \\
\hline Linoleic acid C 18:2 & 0.45 & 0.52 & 0.71 \\
\hline$\alpha$ - Linolenic C 18:3 & 2.01 & 1.99 & 1.69 \\
\hline Unsaturated (U) & 93.81 & 93.61 & 91.55 \\
\hline $\begin{array}{l}\text { Unsaturated:saturated } \\
\text { (U/S) }\end{array}$ & 15.16 & 14.65 & 10.83 \\
\hline
\end{tabular}

Table 5: Fatty acid composition of castor bean oil (expressed as $\%$ of total fatty acid composition).
Similar results were found for the fatty acid composition of the oil extracted from the castor oil plant seeds that were grown in the uncontaminated area. Unsaturated fatty acids were again dominant with their amount reaching $91.55 \%$. The oil composition is dominated by ricinoleic acid (C18:1r, 73.06\%), followed by oleic acid (C18:1, 16.09\%), linolenic acid (C18:3, 1.69\%) and linoleic acid (C18:2, 0.71\%). The saturated fatty acids predominantly comprise of palmitic acid (C16:0) at $4.37 \%$, followed by the stearic acid $(4.08 \%)$.

The content of stearic acid reaches $2.24 \%$ which is higher than the data available in literature, and displays a trend towards an increase in the amount of acid in the cultivation of the castor oil plant in uncontaminated areas. Similar results are obtained from Olivares., et al. [11], which show differences in the content of stearic acid (0.95-1.43\%) between the castor oil plants from contaminated and uncontaminated tailings, with the highest content of stearic acid being found in the case of cultivation on the tailings with the highest content of heavy metals.

The content of oleic acid is significantly higher than the values reported in literature, having a value of $13.40 \%$ in the case of cultivation of the castor oil plant on contaminated soil and $16.04 \%$ in the case of its cultivation on uncontaminated soil. The results obtained by Gonzales-Chavez., et al. (2015) show the opposite trend.

The content of palmitic acid is significantly higher than the values reported in literature; it ranges from 3.95 to 4.37 and is not substantially influenced by the content of heavy metals in soil. According to the results of Costa., et al. [20] and Gonzales-Chaves., et al. [13], the palmitic acid content ranges from 0.47 to $0.91 \%$ and there are no differences between the cultivated plants on tailings with different content of metals.

The content of linoleic acid is significantly lower than the values reported in literature; it ranges from 0.45 to $0.71 \%$, and decreases as the content of heavy metals in soil increases.

The oil tested by us is comprised predominantly of ricinoleic acid, however its amount is lower than the values for the castor oil reported in literature. The lower content of ricinoleic acid in the oil tested by us is likely due to the different climatic conditions of cultivation of the castor oil plant [33]. 
The content of ricinoleic acid is the highest in the cultivation of the castor oil plant on highly contaminated soils (77.85\%), and falls to 73.06 in the castor oil plant from the uncontaminated areas. The amount of ricinoleic acid is found to increase when the degree of contamination of the soil with heavy metals increases.

According to Gonzales-Chaves., et al. [13] the ricinoleic acid content ranges from 85 to $90.5 \%$, and there are no differences between the plants grown on tailings with different content of heavy metals.

The obtained results show that the degree of contamination of the soil with heavy metals affects the fat content of the seeds and the composition of the fatty acid of the castor oil. It was found that the contents of ricinoleic acid and linolenic acid are higher in the cultivation of castor oil plant on contaminated soils, while the contents of palmitic, stearic and linoleic acids are higher in the cultivation of castor oil plant on uncontaminated soils. The opposite trend is observed with regards to the fat content of the seeds. The oil content is the highest in the castor oil plant grown on uncontaminated soils (35.8\%). Heavy metal soil contamination lowers the fat content of the seeds $(29.2 \%)$.

The composition of the acids affects the quality of the plant biofuel [20]. The presence of low levels of saturated and polyunsaturated fatty acids and high levels of monounsaturated acids result in the production of a high quality biodiesel. Oils from the castor oil plant grown on contaminated soils meet these conditions. The oleic acid and the linoleic acid are other important acids that determine the properties (combustion quality, cloud point and calorific value) of the biodiesel produced [20,34]. The castor oil plant is a plant that can be used simultaneously for phytoextraction of heavy metals and soils and as biofuel. It can be grown on soils that are not suitable for the cultivation of food crops due to heavy contamination by heavy metals $[35,36]$.

\section{Conclusion}

- There is a clear distinction between the accumulation of heavy metals in the vegetative and reproductive organs of the castor oil plant. The distribution of the heavy metals in the organs of the castor bean exhibits a selective characteristic in the castor oil plant whereby it decreases in the following order: leaves $>$ roots $>$ stems $>$ capsules $>$ seeds.
- The castor oil plant is a crop that has tolerance to heavy metals. The plants are characterized by a great capacity in the absorption and accumulation of $\mathrm{Pb}$ and $\mathrm{Cd}$, while showing no signs of toxicity (chlorosis and necrosis) in content of 40.5 mg. $\mathrm{kg}^{-1} \mathrm{Cd}$, and $2576.0 \mathrm{mg} . \mathrm{kg}^{-1} \mathrm{~Pb}$ in the soil.

- The potential of castor bean to translocate and accumulate $\mathrm{Cd}, \mathrm{Pb}$ and $\mathrm{Zn}$ in the aboveground parts increases with the level of soil contamination. The castor oil plant can be attributed to hyperaccumulators of $\mathrm{Pb}$ and $\mathrm{Cd}$ and accumulators of $\mathrm{Zn}$.

- The oil composition is dominated by ricinoleic acid (C18:1), followed by oleic acid (C18:1), linolenic acid (C18:3) and linoleic acid (C18:2). The saturated fatty acids predominantly comprise of palmitic acid (C16:0) and stearic acid (C18:0).

- The degree of contamination of the soil with heavy metals affects the fat content of the seeds and the composition of the fatty acid of the castor oil. The contents of ricinoleic acid and linolenic acid are higher in the cultivation of castor oil plant on contaminated soils, while the contents of palmitic, stearic and linoleic acids are higher in the cultivation of castor oil plant on uncontaminated soils.

- The castor oil plant is a plant that can be used simultaneously for phytoextraction of heavy metals and soils and as biofuel. It can be grown on soils that are not suitable for the cultivation of food crops due to heavy contamination by heavy metals.

\section{Acknowledgements}

The authors gratefully acknowledge the financial support by the Bulgarian National Science Fund (Project DFNI H04/9).

\section{Conflict of Interest}

The authors declare no financial interest or no conflict of interest exists.

\section{Bibliography}

1. Chaney RL., et al. "Phytoremediation of soils metals". Current Opinion in Biotechnology 8 (1997): 279-284.

2. Abioye OP., et al. "Bioremoval of Zinc in Polluted Soil using Acalypha inferno". Research Journal of Environmental Sciences 9.5 (2015): 249-255. 
3. Ciura J., et al. "The possibility of using crops as metal phytoremediants". Polish Journal of Environmental Studies 14 (2005): 17-20.

4. Lone MI., et al. "Phytoremediation of heavy metal polluted soils and water: Progresses and perspectives". Journal of Zhejiang University Science 9 (2008): 210-220.

5. Kiran BR., et al. "Ricinus communis L. (castor bean) as a potential candidate for revegetating industrial waste contaminated sites in peri-urban Greater Hyderabad: remarks on seed oil". Environmental Science and Pollution Research 24.24 (2017): 19955-19964.

6. Fassler A., et al. "Phytomanagement of metal-contaminated agricultural land using sunflower, maize and tobacco". Nutrient Cycling in Agroecosystems 87 (2010): 339-352.

7. Angelova VR., et al. "Potential of rapeseed (Brassica napus L.) for phytoremediation of soils contaminated with heavy metals". Journal of Environmental Protection and Ecology 18.2 (2017): 468-478.

8. Prasad MNV and Freitas HMO. "Metal hyperaccumulation in plants e biodiversity prospecting for phytoremediation technology". Electronic Journal of Biotechnology 6 (2013): 284-321.

9. Rajkumar M and Freitas SH. "Influence of metal resistant-plant growth promoting bacteria on the growth of Ricinus communis soil contaminated with heavy metals". Chemosphere 71 (2008): 834-842.

10. Huang H., et al. "The phytoremediation potential of bioenergy crop Ricinus communis for DDTs and cadmium co-contaminated soil”. Bioresearch Technology 102 (2011): 11034-11038.

11. Olivares AR., et al. "Potential of castor bean (Ricinus communis L.) for phytoremediation of mine tailings and oil production". Journal of Environmental Management 114 (2013): 316-323.

12. Boda RK., et al. "Ricinus communis L. (castor bean) as a potential candidate for revegetating industrial waste contaminated sites in peri-urban Greater Hyderabad: remarks on seed oil". Environmental Science and Pollution Research 24.24 (2017): 19955-19964.

13. Gonzalez-Chavez MCA., et al. "Crude oil and bioproducts of castor bean (Ricinus communis L.) plants established naturally on metal mine tailings". International Journal of Environmental Science and Technology 12 (2015): 2263.

14. Kiran BR and Prasad MNV. "Ricinus communis L. (Castor bean), a potential multi-purpose environmental crop for improved and integrated phytoremediation". The EuroBiotech Journal 1.2 (2017): 101-116.

15. Kulkarni MG and Sawant SB. "Some physical properties of castor oil esters and hydrogenated castor oil esters". European Journal of Lipid Science and Technology 105 (2017): 214-218.

16. Bagali SS., et al. "Optimization and Characrerization of Castor Seed Oil”. Leonardo Journal of Sciences 17 (2010): 59-70.

17. Wiley RG and Oeitmann TN. "Ricin and related plant toxins: Mechanisms of action And Neurobiological Applications". Handbook of natural toxins 6 (1991): 346-348.

18. Khan MJ., et al. "Evaluation of phytoremediation potential of castor cultivars for heavy metals from soil". Planta Daninha 37 (2017): e019180998.

19. Zhang H., et al. "Cadmium accumulation and tolerance of two castor cultivars in relation to antioxidant systems". Journal of Environmental Sciences 26.10 (2014): 2048-2055.

20. Costa ET de S., et al. "Assessing the Tolerance of Castor Bean to $\mathrm{Cd}$ and $\mathrm{Pb}$ for Phytoremediation Purposes". Biological Trace Element Research 145 (2012): 93-100.

21. ISO 11466. Soil quality - Extraction of trace elements soluble in aqua regia (1995).

22. ISO 14780. Soil Quality- Extraction of Trace Elements by Buffered DTPA Solution (2001).

23. ISO 5509. Animal and vegetable fat and oils - Preparation of methyl esters of fatty acids (2000).

24. ISO 5508. Animal and vegetable fat and oils - Determination of methyl esters of fatty acids (Gas chromatographic method) (2000).

25. Romeiro S., et al. "Lead uptake and tolerance of Ricinus communis L". Brazilian Journal of Plant Physiology 18.4 (2006): 483489. 
26. Shi G and Cai Q. "Cadmium tolerance and accumulation in eight potential energy crops”. Biotechnology Advances 27 (2009): 555-561.

27. Varun M., et al. "Metal contamination of soils and plants associated with the glass industry in North Central India: prospects of phytoremediation". Environmental Science and Pollution Research 19 (2012): 269-281.

28. Mani D and Kumar C. "Biotechnological advances in bioremediation of heavy metals contaminated ecosystems: an overview with special reference to phytoremediation". International Journal of Environmental Science and Technology 11 (2013): 843-872.

29. Clemens S., et al. "A long way ahead: understanding and engineering plant metal accumulation". Trends in Plant Science 7 (2002): 309-315.

30. Garbisu C and Alkorta I. "Phytoextraction: a cost effective plant-based technology for the removal of metals from the environment". Bioresearch Technology 77 (2001): 229-236.

31. Mazzani E and Rodriguez E. "Estudio de la variabilidad presente en germoplasma de tártago (Ricinus communis L.) en cuanto a racimos, frutos y semillas". Revista Científica UDO Agrícola 9 (2009): 764-769.

32. Manzano P., et al. "Comparación del porcentaje de aceite y del tamaño de seis ecotipos de semillas de higuerilla (Ricinus communis), de origen Sudamericano". Revista tecnologia EPOLRTE 22 (2009): 15-20.

33. Rios Gervasio FA., et al. "Method and phenological characterization of the stadiums and phases of the development of castor bean plants". African Journal of Agricultural Research 11.44 (2016): 4488-4497.

34. Knothe G. "Designer biodiesel: optimizing fatty ester composition to improve fuel properties". Energy Fuel 22 (2008): 3581364.

35. Jumat S., et al. "Fatty Acid composition and Physicochemical Properties of Malaysian Castor Bean Ricinus communis L. Seed Oil". Sains Malaysiana 39.5 (2010): 761-764.

36. Prasad MNV. "Metals in the environment: analysis by biodiversity". New York, Marcel Dekker (2001).

\section{Assets from publication with us}

- Prompt Acknowledgement after receiving the article

- Thorough Double blinded peer review

- Rapid Publication

- Issue of Publication Certificate

- High visibility of your Published work

Website: www.actascientific.com/

Submit Article: www.actascientific.com/submission.php

Email us: editor@actascientific.com

Contact us: +919182824667 